\title{
In situ U-Pb dating of titanite by LA-ICPMS
}

\author{
SUN JinFeng ${ }^{1,2}$, YANG JinHui ${ }^{1 *}$, WU FuYuan ${ }^{1}$, XIE LieWen $^{1}$, YANG YueHeng ${ }^{1}$, \\ LIU ZhiChao ${ }^{1,2}$ \& LI XianHua ${ }^{1}$ \\ ${ }^{1}$ State Key Laboratory of Lithospheric Evolution, Institute of Geology and Geophysics, Chinese Academy of Sciences, Beijing 100029, China; \\ ${ }^{2}$ Graduate University of the Chinese Academy of Sciences, Beijing 100049, China
}

Received January 4, 2012; accepted March 27, 2012; published online May 6, 2012

\begin{abstract}
Titanite is an ideal mineral for $\mathrm{U}-\mathrm{Pb}$ isotopic dating because of its relatively high $\mathrm{U}$, Th and $\mathrm{Pb}$ contents. Here, we developed a technique for U-Pb dating of titanite using the $193 \mathrm{~nm}$ ArF laser-ablation system and Agilent 7500a Q-ICP-MS. Standards of titanite (BLR-1 and OLT-1) and zircon (91500 and GJ-1) were dated using single spot and line raster scan analytical methods. To check the matrix effect, titanite (BLR-1) and zircon (91500) standards were analyzed as the external standards. The weighted mean ${ }^{206} \mathrm{~Pb} /{ }^{238} \mathrm{U}$ ages of OLT- 1 titanite are $1015 \pm 5 \mathrm{Ma}(2 \sigma, n=24)$ and $1017 \pm 6 \mathrm{Ma}(2 \sigma, n=24)$ by single spot and line raster scan analyses, respectively, using BLR-1 titanite as the external standard. These ages are consistent with its reference age of about $1014 \mathrm{Ma}$. However, using 91500 zircon as the external standard, the weighted mean ${ }^{206} \mathrm{~Pb} /{ }^{238} \mathrm{U}$ ages are $917 \pm 4 \mathrm{Ma}(2 \sigma, n=24)$ and $927 \pm 5 \mathrm{Ma}(2 \sigma, n=24)$ for BLR-1 titanite, and $891 \pm 4 \mathrm{Ma}(2 \sigma, n=24)$ and $901 \pm 5 \mathrm{Ma}(2 \sigma, n=24)$ for OLT-1 titanite by single spot and line raster scan analyses, respectively. It is evident that these ages are $\sim 12 \%$ younger than their reference values. Our results reveal that significant matrix effect does exist between different kinds of minerals during LA-ICPMS U-Pb age determination, whereas it is insignificant between same minerals. Therefore, same mineral must be used as the external standard for fractionation corrections during in situ LA-ICPMS U-Pb age analysis. In addition, we determined U-Pb ages for titanites from the Early Cretaceous Fangshan pluton, which indicates a rapid cooling history of this pluton.
\end{abstract}

In situ titanite U-Pb dating, LA-ICPMS, single spot, line raster scan, matrix effect

Citation: $\quad$ Sun J F, Yang J H, Wu F Y, et al. In situ U-Pb dating of titanite by LA-ICPMS. Chin Sci Bull, 2012, 57: 2506-2516, doi: 10.1007/s11434-012-5177-0

Isotopic geochronology is the key to understand the temporal and special evolution of geological bodies and their related geodynamics. There are many analytical methods to date isotopic ages of geological bodies, while the most commonly used is U-Pb dating of accessory minerals [1]. Minerals such as zircon and monazite have high uranium concentration and U-Pb closure temperature $\left(T_{\mathrm{c} \text { (zircon })}>800^{\circ} \mathrm{C}\right.$ [2]; $T_{\mathrm{c} \text { (Monazite) }} 750^{\circ} \mathrm{C}$ [3]) with low common lead, which makes them to be the preferred target for $\mathrm{U}-\mathrm{Pb}$ dating. However, zircon and monazite are relatively stable and cannot be reset by the later thermal and chemical processes, due to its physical and chemical resistance. Thus, they are hardly used to constrain the later metamorphic ages of metamorphosed and hydrothermally altered rocks [4,5].

*Corresponding author (email: jinhui@mail.iggcas.ac.cn)
Furthermore, some rocks (e.g. ultramafic rocks) do not contain zircon and monazite. Titanite $\left(\mathrm{CaTiSiO}_{5}\right)$ is one of the common accessory minerals in igneous rocks, and also occurring in metamorphic, hydrothermal and some sedimentary rocks [5-8]. It usually has relatively high $U$ content (10-100 ppm [7]), which is commonly hold in its crystal lattice. It also has a relatively high $\mathrm{U}-\mathrm{Pb}$ closure temperature of $650-700^{\circ} \mathrm{C}[9,10]$, making it an attractive phase as a geochronometer. Moreover, different with zircon and monazite, titanite is mainly composed by major elements of rocks, which easily exchange with other minerals and react with fluid and melt. Thus, it can record multistage metamorphism events, which are used to constitute the $P-T-t$ path and to constrain the evolution of the metamorphic rocks [4-7]. The U-Pb ages of titanites in igneous rocks may represent the initial crystallization event because of the 
relatively uncommon occurrence of inherited older titanites in these rocks [10,11]; whereas, titanites in metamorphic rocks have different colors and distinct ages [7,11,12], recording multiple thermal events related to later metamorphism, deformation, and hydrothermal alteration of the rocks.

Firstly, titanite $\mathrm{U}-\mathrm{Pb}$ age was obtained using conventional isotope dilution thermal ionization mass spectrometry (ID-TIMS) method [13]. The ID-TIMS U-Pb dating method usually gives the ages with high precision. However, bulk analysis of several mineral grains has missed the microgeological information within single grain $[1,12]$. With development of high sensitivity and spatial resolution analytical instruments, such as secondary ion mass spectrometry (SIMS) $[12,14,15]$, laser ablation multi-collector inductively coupled plasma mass spectrometry (LA-MC-ICPMS) [16-18] and laser ablation quadrupole inductively coupled plasma mass spectrometry (LA-ICPMS) [4,19-21], isotopic ratios in sub-grain-scale domains can be measured [1]. SIMS analysis has strict requirements of the standard sample because of significant matrix effects between different mineral components $[14,15]$. In contrast, LA-ICPMS instruments are cheap and can achieve rapid analysis with sample preparation, making it a preferred tool for titanite $\mathrm{U}-\mathrm{Pb}$ age determination [1,4,19-21]. However, it is still controversial about the matrix effect during LA-ICPMS U-Pb age analysis. Many researchers believe that determination of $\mathrm{U}-\mathrm{Pb}$ age of accessory mineral by LA-ICPMS has no significant matrix effect and can use different mineral as external standard [1]. However, Black et al. [14] have reported significant matrix effect between different composed zircons during LA-ICPMS U-Pb dating, which attributing to the age bias with ID-TIMS value. In addition, some researchers chose line raster scan mode to reduce the matrix effect of different minerals as $\mathrm{U}-\mathrm{Pb}$ fractionation correction $[4,19,20]$. Therefore, for LA-ICPMS U-Pb age determination, whether different minerals can be used as external standard for fractionation correction is still not well studied.

In this work, two analytical modes, i.e. single spot and line raster scan analyses were used for U-Pb age determination of BLR-1 and OLT-1 titanites, and 91500 and GJ-1 zircons by LA-ICPMS, with the aim of detecting the matrix effect between different minerals and establishing feasible LA-ICPMS titanite $\mathrm{U}-\mathrm{Pb}$ dating method. Moreover, the LA-ICPMS U-Pb dating method was applied in the Fangshan pluton to constrain its cooling history.

\section{Instrumentation}

$\mathrm{U}-\mathrm{Pb}$ age measurements in this study were conducted using a quadrupole inductively coupled plasma mass spectrometry (Q-ICPMS), equipped with a $193 \mathrm{~nm} \mathrm{ArF} \mathrm{excimer} \mathrm{laser}$ ablation system hosted at the Institute of Geology and Geophysics, Chinese Academy of Sciences. Detailed description of the Agilent 7500a Q-ICPMS can be found in references [22-25].

The GeoLas Pro excimer laser ablation system is made by Coherent $\mathrm{GmbH}$ in Germany, and mainly consisted of three parts: (1) a COMPex PRO 102F ArF excimer laser generator with wavelength of $193 \mathrm{~nm}$, pulse width of $15 \mathrm{~ns}$ and maximum energy of $200 \mathrm{~mJ}$; (2) a laser optical system with a laser beam homogenizing system. The laser spot size can be adjusted to $5,10,16,24,32,44,60,90,120$ and $160 \mu \mathrm{m}$ with frequency from 1 to $20 \mathrm{~Hz}$; and (3) Geolas Pro standard software. The highest energy density is $45 \mathrm{~J} / \mathrm{cm}^{2}$, and $10-15 \mathrm{~J} / \mathrm{cm}^{2}$ were used in this study.

\section{Analytical method}

Sample preparation and analytical method for titanite U-Pb dating in this work are similar with descriptions in references [22-25]. The Pulse/Analogy (P/A) factor was corrected using the P/A calibration solution before routine analysis. A tuning solution was also used to optimize the instrumental parameters to make productivities of oxide $\left(\mathrm{CeO}^{+} / \mathrm{Ce}^{+}\right)$and doubly charged $\mathrm{Ce}^{2+} / \mathrm{Ce}^{+}$less than $1 \%$ and $3 \%$, and sensitivity for ${ }^{89} \mathrm{Y}$ better than $200 \mathrm{Mcps} / \mathrm{ppm}$. During laser-ablation, the instrument was optimized using NIST SRM 610 standard glass. The detailed parameters are shown in Table 1. ICP-MS measurements were carried out using time-resolved analysis and peak hopping at one point per mass. The dwell times were $10 \mathrm{~ms}$ for ${ }^{29} \mathrm{Si},{ }^{43} \mathrm{Ca},{ }^{232} \mathrm{Th}$ and ${ }^{238} \mathrm{U}, 15 \mathrm{~ms}$ for ${ }^{204} \mathrm{~Pb},{ }^{206} \mathrm{~Pb}$ and ${ }^{208} \mathrm{~Pb}, 30 \mathrm{~ms}$ for ${ }^{207} \mathrm{~Pb}$. Each spot analysis consisted of a $30 \mathrm{~s}$ background acquisition and $60 \mathrm{~s}$ sample data acquisition and $60 \mathrm{~s}$ for cleaning the sample cell and plumbing lines. Every 8 samples analyzed were followed by two standard titanite BLR-1, two standard zircon 91500, one GJ-1 zircon and one NIST SRM 610 measurements. The $44 \mu \mathrm{m}$ spot size and $6 \mathrm{~Hz}$ ablation frequency were used for single spot analysis; $44 \mu \mathrm{m}$ spot size, $6 \mathrm{~Hz}$ ablation frequency and $2 \mu \mathrm{m} \mathrm{s}^{-1}$ scanning speed were used for line raster scan analysis.

$\mathrm{U}$, Th and $\mathrm{Pb}$ concentrations were calibrated using ${ }^{43} \mathrm{Ca}$ as the internal calibration for titanites, using NIST SRM 610 as the reference material $(\mathrm{CaO}$ concentration of titanites from the Fangshan pluton is 28.4\% [23]). Both standard titanite BLR-1 and standard zircon 91500 were used as the external standard for $\mathrm{U}-\mathrm{Pb}$ fractionation correction of single spot and line raster scan analyses, respectively. ${ }^{207} \mathrm{~Pb} /{ }^{206} \mathrm{~Pb}$ and ${ }^{206} \mathrm{~Pb} /{ }^{238} \mathrm{U}$ ratios were calculated using the GLITTER program [26]. Standard deviations (SDs) of calibrated isotope ratios include those from sample, external standard (BLR-1 titanite or 91500 zircon), and reference values. The relative standard deviations of reference values for the external standards were set at $2 \%$.

Since ${ }^{204} \mathrm{~Pb}$ signal intensity was much lower than the other $\mathrm{Pb}$ isotopes and suffered a large isobaric interference from ${ }^{204} \mathrm{Hg}$, thus hard to be accurately determined. Common 
Table 1 Parameters of LA-ICPMS

\begin{tabular}{|c|c|}
\hline \multicolumn{2}{|r|}{ Q-ICPMS } \\
\hline Instrument & Agilent $7500 \mathrm{a}$ \\
\hline RF forward power & $1380 \mathrm{~W}$ \\
\hline Reflect RF power & $<3 \mathrm{~W}$ \\
\hline Cooling gas & Ar: $15 \mathrm{~L} \mathrm{~min}^{-1}$ \\
\hline Auxiliary gas & Ar: $1.2 \mathrm{~L} \mathrm{~min}^{-1}$ \\
\hline Sample depth & $4.8 \mathrm{~mm}$ \\
\hline Interface cones & Nickel \\
\hline Sensitivity & $\begin{array}{l}200 \mathrm{Mcps} / \mathrm{ppm} \text { on }{ }^{89} \mathrm{Y} \text { signal via } 100 \mu \mathrm{L} \mathrm{min}^{-1} \\
\text { PFA microflow nebulizer }\end{array}$ \\
\hline Integration time & $\begin{array}{l}10 \mathrm{~ms} \text { for }{ }^{29} \mathrm{Si},{ }^{43} \mathrm{Ca},{ }^{232} \mathrm{Th} \text { and }{ }^{238} \mathrm{U} ; 15 \mathrm{~ms} \text { for } \\
{ }^{204} \mathrm{~Pb},{ }^{206} \mathrm{~Pb} \text { and }{ }^{208} \mathrm{~Pb} ; 30 \mathrm{~ms} \text { for }{ }^{207} \mathrm{~Pb}\end{array}$ \\
\hline Analytical time/spot & $\begin{array}{l}150 \mathrm{~s} \text { ( } 30 \mathrm{~s} \text { background acquisition; } 60 \mathrm{~s} \text { sample } \\
\text { data acquisition; }>60 \mathrm{~s} \text { for cleaning the sample } \\
\text { cell and plumbing lines) }\end{array}$ \\
\hline \multicolumn{2}{|r|}{ Laser ablation system } \\
\hline Instrument & COMPex PRO 102F, ArF excimer \\
\hline Wavelength & UV $193 \mathrm{~nm}$ \\
\hline Energy density & $\begin{array}{l}\text { maximum } 45 \mathrm{~J} \mathrm{~cm}^{-2}, 10-12 \mathrm{~J} \mathrm{~cm}^{-2} \text { were used in } \\
\text { this work }\end{array}$ \\
\hline Energy & $80-100 \mathrm{~J}$ \\
\hline Laser spot size & $\begin{array}{l}60 \mu \mathrm{m} \text { for titanites from the Fangshan pluton; } \\
44 \mu \mathrm{m} \text { for others }\end{array}$ \\
\hline Raster scanning speed & $2 \mu \mathrm{m} \mathrm{s}^{-1}$ \\
\hline Pulse rate & $6 \mathrm{~Hz}$ \\
\hline Carrier gas & He: $0.6 \mathrm{~L} \mathrm{~min}^{-1}$ \\
\hline
\end{tabular}

lead correction for zircons was applied using the method described by Andersen [27] for its low common lead content; the measured, uncorrected, compositions of titanites were plotted on a Tera-Wasserburg Concordia diagram [28], defined a line which intersects the Concordia line at upper and lower representing the common lead composition and the age of the sample, respectively. The measured ${ }^{207} \mathrm{~Pb}$ was also applied for common lead correction, and obtained the ${ }^{206} \mathrm{~Pb} /{ }^{238} \mathrm{U}$ age [23]. Common lead compositions of BLR-1, OLT-1 and Ontario titanites were calculated using the twostage model of Stacey and Kramers [29] and the assumed ages. They all give the homogenous initial ${ }^{207} \mathrm{~Pb} /{ }^{206} \mathrm{~Pb}=0.91$ \pm 0.02 , which used for their common lead correction. All of the weighted mean ${ }^{206} \mathrm{~Pb} /{ }^{238} \mathrm{U}$ ages were calculated using Isoplot/Ex v. 3.0 [30].

\section{Results}

\subsection{BLR-1 titanite as the external standard}

$\mathrm{U}-\mathrm{Pb}$ isotopes of titanites (BLR-1, OLT-1 and Ontario) were measured by LA-ICPMS using single spot analysis, while BLR-1 and OLT-1 titanites were chosen for line raster scan mode. BLR-1 titanite was used as the external standard for $\mathrm{U}-\mathrm{Pb}$ fractionation correction. All of the results are shown in Figures 1, 2 and Table S1.

BLR-1 titanite. It is a metamorphic megacryst collected from Ontario of Canada. As one of the most widely used standards for titanite SIMS U-Pb dating, it is rarely used for LA-ICPMS U-Pb age determination [21]. The ID-TIMS analyses by Aleinikoff et al. [31] gave a weighted mean ${ }^{207} \mathrm{~Pb} /{ }^{235} \mathrm{U}$ age of $1048.0 \pm 0.7 \mathrm{Ma}(2 \sigma, n=5, \mathrm{MSWD}=2.8)$, ${ }^{207} \mathrm{~Pb} /{ }^{206} \mathrm{~Pb}$ age of $1049.9 \pm 1.3 \mathrm{Ma}(2 \sigma, n=5, \mathrm{MSWD}=2.9)$ and a relatively uniform ${ }^{206} \mathrm{~Pb} /{ }^{238} \mathrm{U}$ age of $1047.1 \pm 0.4 \mathrm{Ma}$ $(2 \sigma, n=5, \mathrm{MSWD}=0.56)$. Moreover, the detailed major and trace elements compositions have also been analyzed in the previous study [32].

Twenty-four single spot analyses have been conducted on BLR-1 titanite and plotted near the Concordia line on a Tera-Wasserburg Concordia diagram [28]. They yielded a weighted mean ${ }^{206} \mathrm{~Pb} /{ }^{238} \mathrm{U}$ age of $1046 \pm 5 \mathrm{Ma}(2 \sigma, n=24)$ (Figure 1(a), (b)) after ${ }^{207} \mathrm{~Pb}$-correction. Twenty-four analysis by line raster scan mode give a weighted mean ${ }^{206} \mathrm{~Pb} /$ ${ }^{238} \mathrm{U}$ age of $1046 \pm 6 \mathrm{Ma}(2 \sigma, n=24)$ (Figure 2(a), (b)). They are similar to the reference data and show low common $\mathrm{Pb}$ content and homogenous $\mathrm{U}-\mathrm{Pb}$ isotope distribution in the BLR-1 titanite.

OLT-1 titanite. This sample is dark brown titanite grain collected from pegmatite skarns of the Grenville Province of the Canadian Shield. Kennedy et al. [33,34] obtained a concordia age of $1014.7 \pm 3.8 \mathrm{Ma}(n=3, \mathrm{MSWD}=3.4)$ from three titanite grains using solution analyses, while the other grain gave an older age due to the influence of surface common lead. Comprehensive analyses of SIMS, Raman, EBSD, EPMA-WDS and U-Th-He dating conclude OLT-1 titanite has potential as international reference material, with $\mathrm{U}-\mathrm{Pb}$ heterogeneity smaller than that of the Khan titanite [35]. OLT-1 titanite has no U-Pb age data reported using other techniques.

Twenty-four single spot analyses of OLT-1 titanite were carried out and plotted on a Tera-Wasserburg Concordia diagram. They defined a mixing line using the initial $\mathrm{Pb}$ composition calculated as two-stage model of Stacey and Kramers [29] and yield a lower intercept age of 1017 $\pm 5 \mathrm{Ma}$ (Figure 1(c)). After ${ }^{207} \mathrm{~Pb}$-correction, they give a weighted mean ${ }^{206} \mathrm{~Pb} /{ }^{238} \mathrm{U}$ age of $1015 \pm 5 \mathrm{Ma}(2 \sigma, n=24)$ (Figure $1(\mathrm{~d})$ ). Twenty-four line raster scan analyses of OLT-1 titanite give a lower intercept age of $1019 \pm 6 \mathrm{Ma}$ (Figure 2(c)) and a weighted mean ${ }^{206} \mathrm{~Pb} /{ }^{238} \mathrm{U}$ age of $1017 \pm 6 \mathrm{Ma}(2 \sigma, n=24)$ (Figure 2(d)). All of these ages are identical to the reference value of $1014 \mathrm{Ma}[33,34]$, within errors.

Ontario titanite. This is a dark brown single crystal collected from the Renfrew district of Ontario, Canada, same place with the international zircon standard 91500. Detailed $\mathrm{U}-\mathrm{Pb}$ age determinations have been conducted using LAICPMS, with the aim of standard material investigation.

The crystal size in this study was about $1.5 \mathrm{~cm} \times 1 \mathrm{~cm} \times$ $0.5 \mathrm{~cm}$. Twenty-eight single spot analyses have been conducted on this grain, and the results are shown in Figure 1(e), 

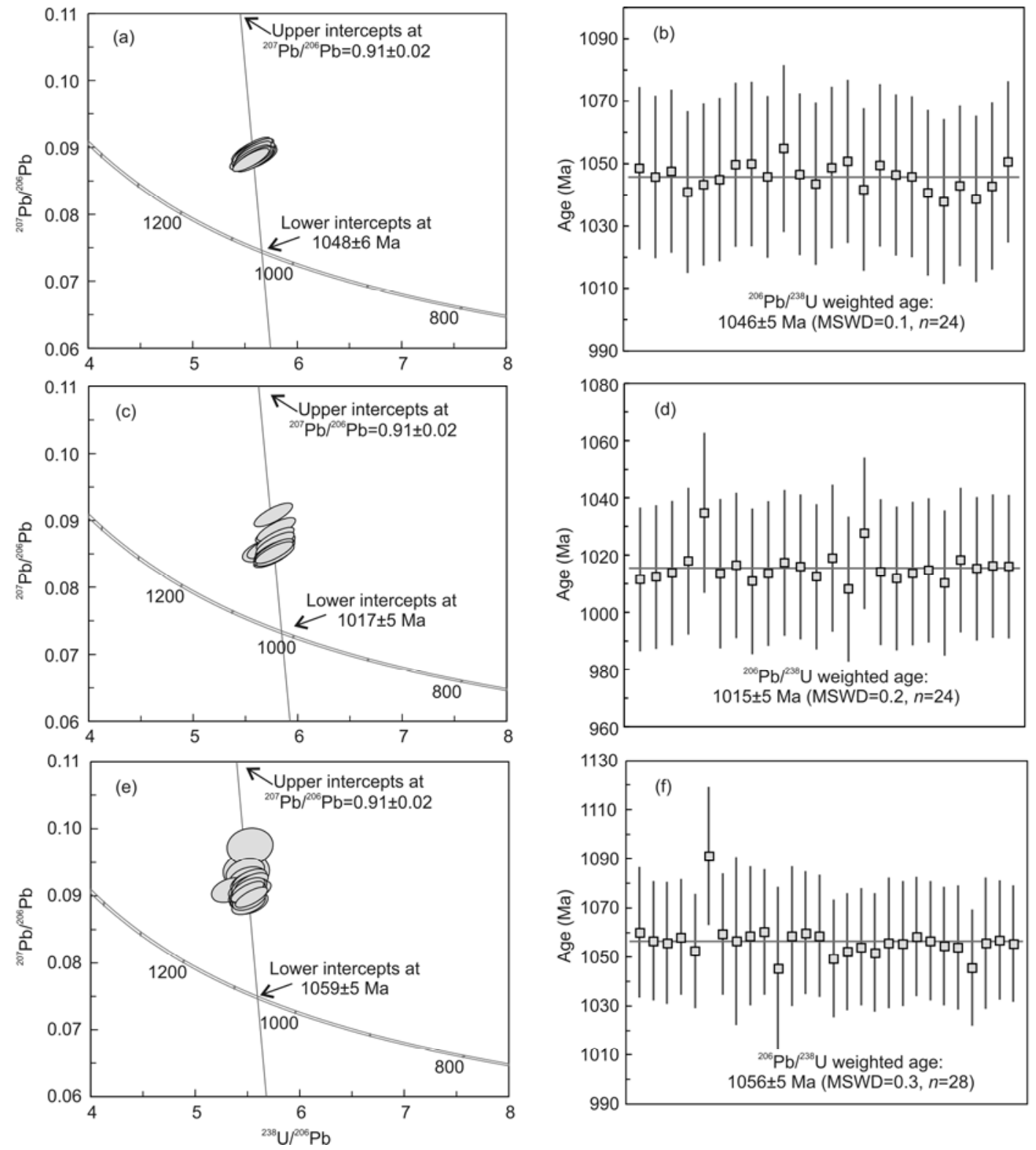

Figure 1 U-Pb dating of titanites by LA-ICPMS using single spot analyses with BLR-1 titanite as the external standard. (a), (b) BLR-1 titanite; (c), (d) OLT-1 titanite; (e), (f) Ontario titanite; (b), (d), (f) ${ }^{207} \mathrm{~Pb}$-corrected age.

(f) and Table S1. All spots were clustered near the Concordia line on a Tera-Wasserburg Concordia diagram, yielding consistent lower intercept and weighted mean ${ }^{206} \mathrm{~Pb} /{ }^{238} \mathrm{U}$ ages of $1059 \pm 5 \mathrm{Ma}$ (Figure 1(e)) and $1056 \pm 5 \mathrm{Ma}(2 \sigma, n=28)$ (Figure 1(f)), within errors.

\subsection{0 zircon as the external standard}

$\mathrm{U}-\mathrm{Pb}$ ages of 91500 and GJ-1 zircons were determined simultaneously with BLR-1 and OLT-1 titanites by LA-ICPMS using single spot and line raster scan modes, with identical instrument and analytical parameters $(44 \mu \mathrm{m}$ spot size, $6 \mathrm{~Hz}$ frequency and $2 \mu \mathrm{m} \mathrm{s}^{-1}$ scanning speed). 91500 zircon was used as the external standard for $\mathrm{U}-\mathrm{Pb}$ fractionation correc- tion, and the results are shown in Figures 3, 4 and Tables S1 and $\mathrm{S} 2$.

(1) GJ-1 zircon. Twenty-two single spot analyses yield a concordia age of $605 \pm 3 \mathrm{Ma}$ and a weighted mean ${ }^{206} \mathrm{~Pb} /{ }^{238} \mathrm{U}$ age of $605 \pm 3 \mathrm{Ma}(2 \sigma, n=22)$ (Figure 3(a),(b)) after common lead correction using Andersen [27] method. Twenty-three line raster scan analyses give a concordia age of $603 \pm 3 \mathrm{Ma}$, and a weighted mean ${ }^{206} \mathrm{~Pb} /{ }^{238} \mathrm{U}$ age of $603 \pm 3 \mathrm{Ma}(2 \sigma, n=23)$ (Figure 4(a),(b)). They are well consistent with the reference values of 600-613 Ma [22,36,37].

(2) BLR-1 titanite. Using 91500 zircon as the external standard, U-Pb isotopic ratios of BLR-1 titanite by single spot and line raster scan modes were corrected and plotted on a Tera-Wasserburg Concordia diagram (Figures 3(c), 4(c)). 

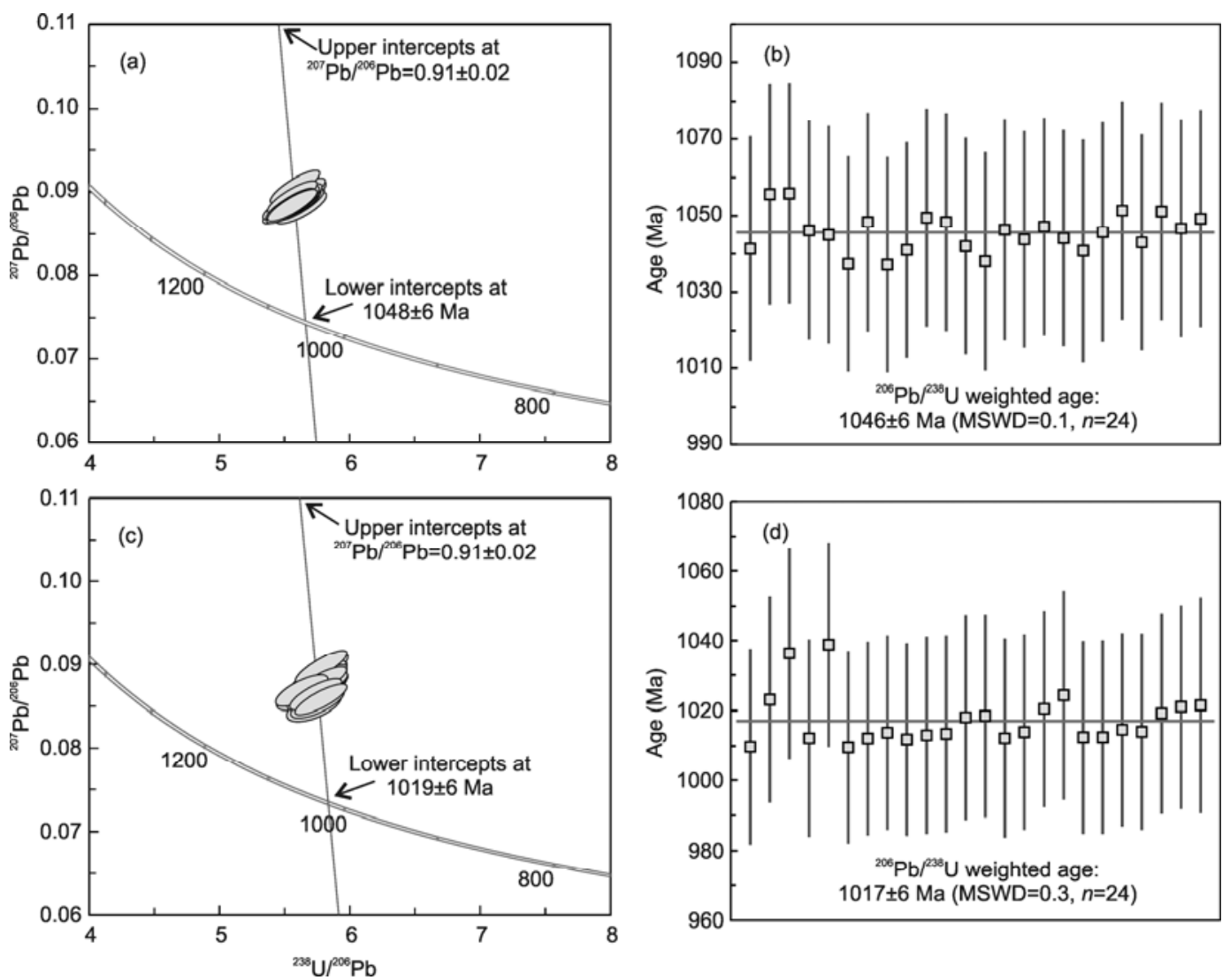

Figure 2 U-Pb dating of titanites by LA-ICPMS using line raster scan mode with BLR-1 titanite as the external standard. (a), (b) BLR-1 titanite; (c), (d) OLT-1 titanite; (b), (d) ${ }^{207} \mathrm{~Pb}$-corrected age.

The obtained lower intercept age and weighted mean ${ }^{206} \mathrm{~Pb} /$ ${ }^{238} \mathrm{U}$ age are $919 \pm 4 \mathrm{Ma}$ (Figure 3(c)) and $917 \pm 4 \mathrm{Ma}(2 \sigma, n=$ 24) (Figure 3(d)) for single spot analyses, $929 \pm 5 \mathrm{Ma}$ (Figure 4(c)) and 927 $\pm 5 \mathrm{Ma}(2 \sigma, n=24)$ (Figure 4(d)) for line raster scan analyses. All of the ages are $\sim 12 \%$ younger than the reference value (1047 Ma) of BLR-1 titanite.

(3) OLT-1 titanite. U-Pb isotopic ratios of OLT-1 titanite were corrected using 91500 zircon as the external standard, and the results were plotted on a Tera-Wasserburg Concordia diagram (Figures 3(e), 4(e)). The obtained lower intercept age and weighted mean ${ }^{206} \mathrm{~Pb} /{ }^{238} \mathrm{U}$ age are $893 \pm 4$ Ma (Figure 3(e)) and 891 $\pm 4 \mathrm{Ma}(2 \sigma, n=24)$ (Figure 3(f)) for single spot analyses, $903 \pm 5 \mathrm{Ma}$ (Figure 4(e)) and 901 $\pm 5 \mathrm{Ma}$ $(2 \sigma, n=24)$ (Figure 4(f)) for line raster scan analyses. They are also $\sim 12 \%$ younger than the reference value (1014 Ma) of OLT-1 titanite.

\subsection{Titanite $\mathrm{U}-\mathrm{Pb}$ ages of the Fangshan pluton}

The Fangshan pluton, located to the cross site of the YFTB and the Taihang Mountain in the eastern North China Craton, is one of the Early Cretaceous intrusions formed during the "Late Yanshanian" event [23]. It is a magmatic diapir intruded into the upper crust, forming a typical "doming" structure $[38,39]$. It occurs as a ring complex, with an outer annulus of quartz monzodiorite surrounding a central core of granodiorite with abundant mafic microgranular enclaves [23]. Six samples were collected from the outer to the central part of Fangshan pluton for titanite U-Pb dating. Using BLR-1 titanite as the external standard for U-Pb fractionation correction, the obtained data were shown in Figure 5 and Table S4. The measured isotopic ratios were plotted on a Tera-Wasserburg Concordia diagram [28], yielding the common lead composition and the age of sample corresponding to the upper and lower intercepts.

(1) Quartz monzodiorite. The lower and upper intercept ages of sample $08 \mathrm{FS} 02$ are $133 \pm 4 \mathrm{Ma}$ and $4797 \pm 470 \mathrm{Ma}$, corresponding to a common lead composition of ${ }^{207} \mathrm{~Pb} /{ }^{206} \mathrm{~Pb}$ $=0.7330 \pm 0.1203$. The weighted mean ${ }^{206} \mathrm{~Pb} /{ }^{238} \mathrm{U}$ age of titanite corrected using ${ }^{207} \mathrm{~Pb}$ is $133 \pm 1 \mathrm{Ma}(n=18$, MSWD $=$ 0.32 ), identical to its lower intercept age (Figure 5(a)) and zircon U-Pb age of $134 \pm 1 \mathrm{Ma}(n=23, \mathrm{MSWD}=0.79)$ [23] obtained by SIMS, within errors.

(2) Medium-grained granodiorite. The lower and upper intercept ages are $133 \pm 4 \mathrm{Ma}$ and $4892 \pm 120 \mathrm{Ma}$ for titanites in the sample 08FS08, 132 $\pm 16 \mathrm{Ma}$ and $5043 \pm 430 \mathrm{Ma}$ for titanites in the sample 08FS10, respectively. Based on the common lead compositions of ${ }^{207} \mathrm{~Pb} /{ }^{206} \mathrm{~Pb}=0.7836 \pm 0.0330$ and $0.8715 \pm 0.1323$, the obtained weighted mean ${ }^{206} \mathrm{~Pb} /{ }^{238} \mathrm{U}$ ages are $132 \pm 2 \mathrm{Ma}(n=20, \mathrm{MSWD}=0.16)$ for $08 \mathrm{FS} 08$ and 

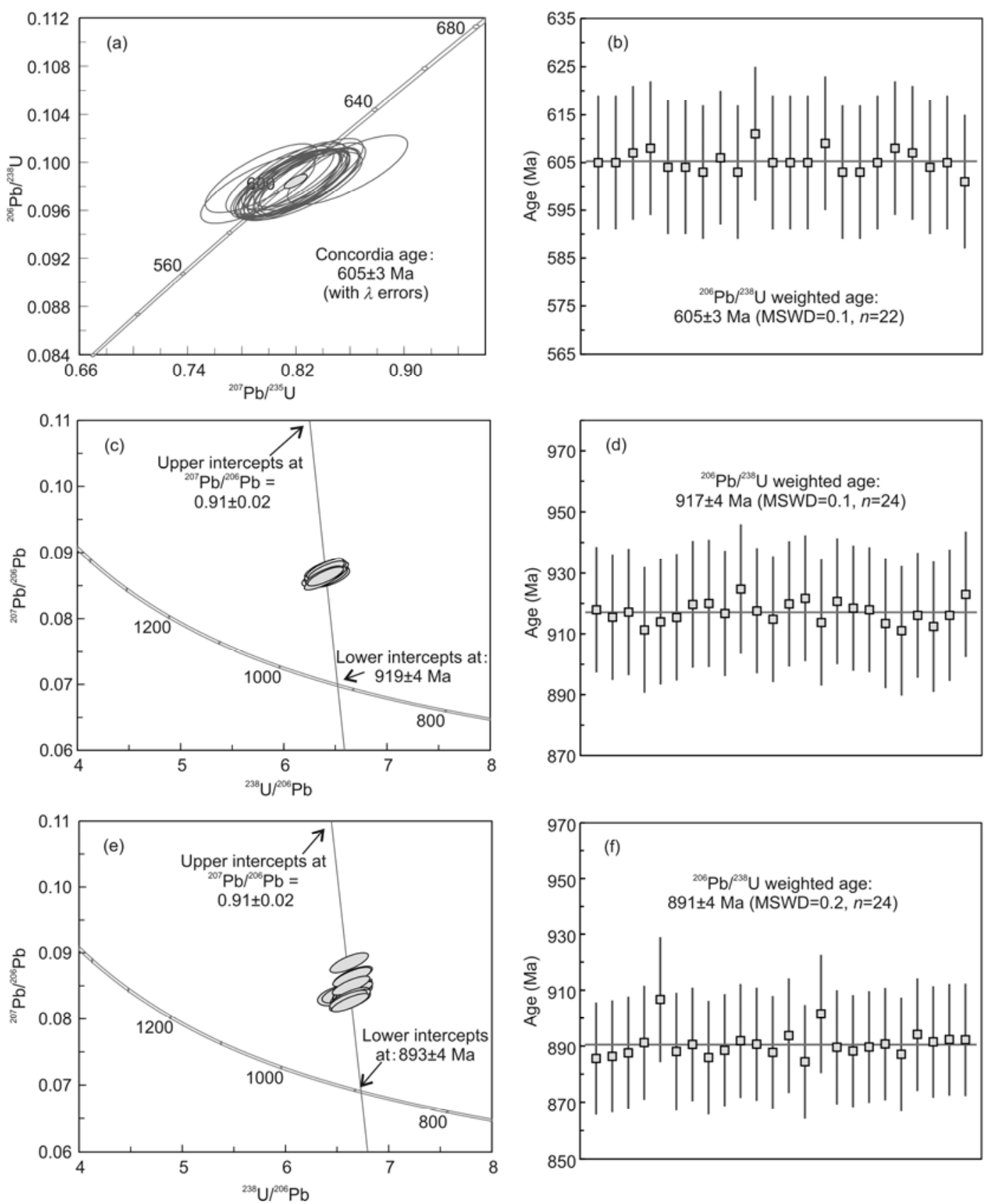

Figure 3 U-Pb dating of titanites and GJ-1 zircon by LA-ICPMS using single spot mode with 91500 zircon as the external standard. (a), (b) GJ-1 zircon; (c), (d) BLR-1 titanite; (e), (f) OLT-1 titanite; (d), (f) ${ }^{207} \mathrm{~Pb}$-corrected age.

131 \pm 4 Ma ( $n=18, \mathrm{MSWD}=0.06$ ) for 08FS10 (Figure 5(b), (c)). Both the lower intercept ages and the weighted mean ${ }^{206} \mathrm{~Pb} /{ }^{238} \mathrm{U}$ ages are identical to $08 \mathrm{FS} 10$ zircon $\mathrm{U}-\mathrm{Pb}$ age of $132 \pm 1 \mathrm{Ma}(n=28, \mathrm{MSWD}=0.21)$ [23] obtained by SIMS, within errors.

(3) Porphyritic granodiorite. The lower and upper intercept ages of titanites in the sample $08 \mathrm{FS} 13$ are $133 \pm 13 \mathrm{Ma}$ and $5082 \pm 140 \mathrm{Ma}$, corresponding to a common lead ${ }^{207} \mathrm{~Pb} /{ }^{206} \mathrm{~Pb}$ value of $0.8957 \pm 0.0444$. Using the ${ }^{207} \mathrm{~Pb}$-correction method, the obtained weighted mean ${ }^{206} \mathrm{~Pb} /{ }^{238} \mathrm{U}$ age is $130 \pm 5 \mathrm{Ma}(n=$ 20, MSWD=0.33), consistent with the lower intercept age
(Figure 5(d)). Zircon U-Pb age of 07FS11 porphyritic granodiorite is $130 \pm 1 \mathrm{Ma}$ (SIMS, $n=24, \mathrm{MSWD}=0.91$ ) [23], coeval with titanite $\mathrm{U}-\mathrm{Pb}$ age within errors.

(4) Mafic enclave. The lower and upper intercept ages are $133 \pm 4 \mathrm{Ma}$ and $5087 \pm 120 \mathrm{Ma}$ for titanites in the sample 08FS07, 132 $\pm 7 \mathrm{Ma}$ and 4986 $\pm 200 \mathrm{Ma}$ for titanites in the sample 08FS09, yielding common lead compositions of ${ }^{207} \mathrm{~Pb} /{ }^{206} \mathrm{~Pb}=0.8990 \pm 0.0382$ and $0.8370 \pm 0.0590$, respectively. After calculation using ${ }^{207} \mathrm{~Pb}$-correction method, the analysis give weighted mean ${ }^{206} \mathrm{~Pb} /{ }^{238} \mathrm{U}$ ages are $132 \pm 2 \mathrm{Ma}(n=20$, $\mathrm{MSWD}=0.27)$ for $08 \mathrm{FS} 07$ and $131 \pm 3 \mathrm{Ma}(n=18, \mathrm{MSWD}=$ 

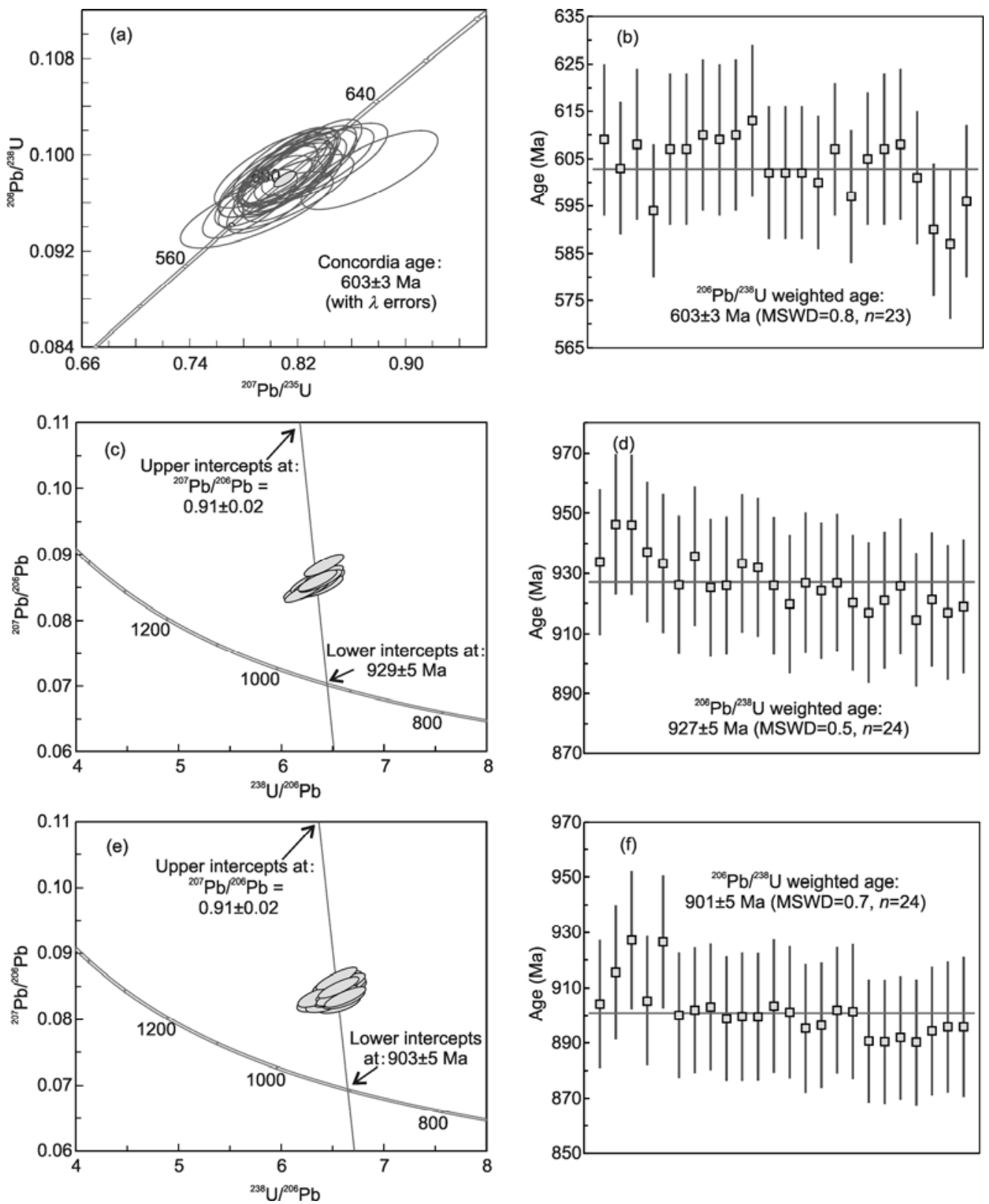

Figure $4 \mathrm{U}$-Pb dating of titanites and GJ-1 zircon by LA-ICPMS using line raster scan mode with 91500 zircon as the external standard. (a), (b) GJ-1 zircon; (c), (d) BLR-1 titanite; (e), (f) OLT-1 titanite; (d), (f) ${ }^{207} \mathrm{~Pb}$-corrected age.

0.16) for 08FS09 (Figure 5(e), (f)). Both the lower intercept ages and weighted mean ${ }^{206} \mathrm{~Pb} /{ }^{238} \mathrm{U}$ ages are well consistent

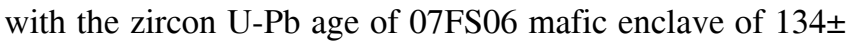
$1 \mathrm{Ma}$ (SIMS, $n=18$, MSWD=0.53) [23], within errors.

\section{Discussion}

\subsection{In situ U-Pb dating of titanite by LA-ICPMS}

Titanite, a common U-bearing accessory mineral with unique mineralogical and geochemical characteristics, can be widely used as a precise and robust geochronometer [1,5,7]. Recently, $\mathrm{U}-\mathrm{Pb}$ dating of titanite has been well developed due to the advances in analytical techniques, providing a provenance tool to solve many geological puzzles [5,16-21,23]. Owing to the lack of titanite standard, some researchers employed zircon as the external standard for establishing LA-ICMS line raster scan titanite $\mathrm{U}-\mathrm{Pb}$ dating method [4,19,20,23]; whereas, Gao et al. [21] and Kohn and Corrie [40] obtained accurate titanite U-Pb ages by LA-ICPMS single spot analyses using BLR-1 titanite as the external standard. In this work, detailed U-Pb ages of BLR-1 and OLT-1 titanites were determined using LA-ICPMS single spot and line raster scan analyses, with the aim of establishing a versatile titanite $\mathrm{U}-\mathrm{Pb}$ dating method.

BLR-1 titanite was commonly used as the external standard 

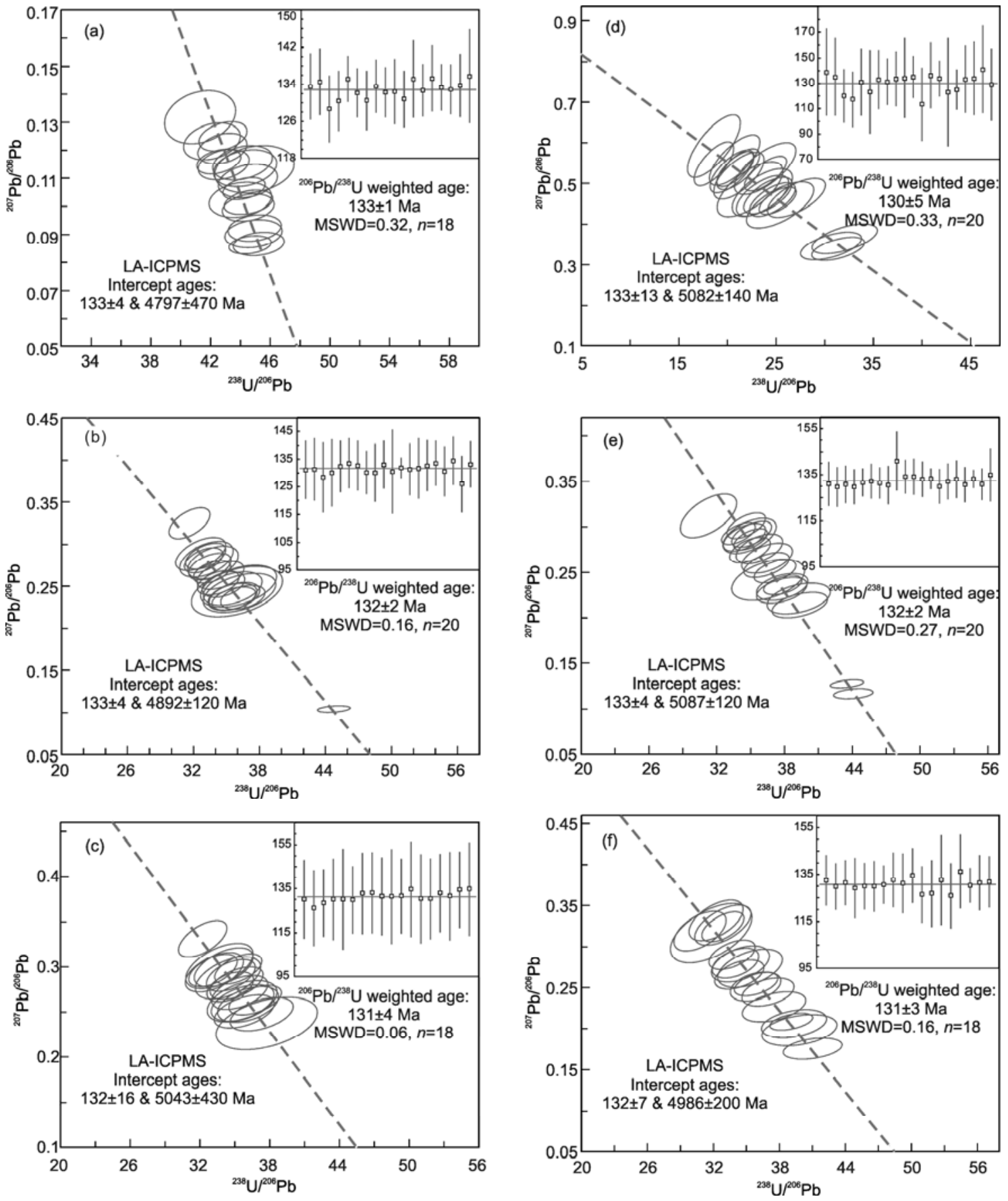

Figure 5 Titanite LA-ICPMS U-Pb ages for the Early Cretaceous Fangshan pluton. (a) 08FS02 quartz monzodiorite; (b) 08FS08 granodiorite; (c) 08FS10 granodiorite; (d) 08FS13 porphyritic granodiorite; (e) 08FS07 mafic enclave; (f) 08FS09 mafic enclave.

for correction of U-Pb fractionation yielded by SHRIMP determination [31,32]. Detailed analytical results reveal a uniform U-Pb geochronology of BLR-1 titanite and can be used as the external standard. The obtained weighted mean ${ }^{206} \mathrm{~Pb} /{ }^{238} \mathrm{U}$ ages of OLT-1 titanite are $1015 \pm 5 \mathrm{Ma}(2 \sigma, n=24)$ (Figure 1(d)) and 1017 $\pm 6 \mathrm{Ma}(2 \sigma, n=24)$ (Figure 2(d)) for LA-ICPMS single spot and line raster scan analyses, well consistent with its references value of $1014 \mathrm{Ma}$ within errors. LA-ICPMS titanite U-Pb dating method in this study is accurate and available and shows the homogeneity of U-Pb ages of BLR-1 titanite using single point and line raster scan modes. Moreover, U-Pb age errors yielded by single spot and line raster scan analyses were identical, implying few influence of erosion depth to $\mathrm{U}-\mathrm{Pb}$ age under conditions of $44 \mu \mathrm{m}$ spot size, $6 \mathrm{~Hz}$ frequency and $2 \mu \mathrm{m} / \mathrm{s}$ scanning speed. All these indicate that the BLR-1 titanite can be used as an external standard during LA-ICPMS U-Pb dating.

$\mathrm{U}-\mathrm{Pb}$ age of Ontario titanite was also obtained by LA- 
ICPMS single spot analyze. Twenty-eight analyses were conducted in a cross on the grain surface using $44 \mu \mathrm{m}$ spot size and $6 \mathrm{~Hz}$ frequency. The result show homogenous U-Pb isotopic compositions of Ontario titanite, yielding a weighted mean ${ }^{206} \mathrm{~Pb} /{ }^{238} \mathrm{U}$ age of $1056 \pm 5 \mathrm{Ma}(2 \sigma, n=28)$ (Figure 1(f)). In addition, Ontario titanite contains relatively high $\mathrm{U}$ and low common lead contents, revealing potential to be used as international reference material. However, it still needs more $\mathrm{U}-\mathrm{Pb}$ age determinations using ID-TIMS technique.

\subsection{Matrix effect of LA-ICPMS U-Pb dating analysis}

It is still controversial about the matrix effect during LAICPMS U-Pb age analysis. Traditional views are that under a certain instrument condition, the important issue to LA-ICPMS U-Pb dating is elemental fractionation during laser ablation and gas transmission. Instead of chemical component, elemental fractionation is mainly related to spot size and sample depth [41,42]. Thus, some researchers suggest that the LA-ICPMS can be widely used for U-Pb dating of any U-Th-Pb-bearing minerals with distinct mineral as the external standard [41,42]. Moreover, the matrix effect can be reduced using line raster scan U-Pb dating method $[4,19,20]$. Therefore, U-Pb ages of titanite have been successfully obtained in many works by LA-ICPMS line raster scan analyses using zircon as the external standard $[4,19,20]$. To investigate the matrix effect during LA-ICPMS U-Pb dating, here we analyzed the U-Pb ages of BLR-1 and OLT-1 titanites, 91500 and GJ-1 zircons using both single point and line raster scan modes.

Our results show that using 91500 zircon as the external standard, both single spot analysis (Figure 3(a), (b)) and line raster scan measurement (Figure 4(a), (b)) give consistent concordia ages of $605 \pm 3 \mathrm{Ma}$ and $603 \pm 3 \mathrm{Ma}$ for GJ- 1 zircon, respectively. These ages are well consistent with its reference value of $610 \mathrm{Ma}$ within errors. However, the weighted mean ${ }^{206} \mathrm{~Pb} /{ }^{238} \mathrm{U}$ ages of BLR-1 and OLT-1 titanites are $917 \pm 4 \mathrm{Ma}(2 \sigma, n=24)$ and $891 \pm 4 \mathrm{Ma}(2 \sigma, n=24)$ using single spot analysis (Figure 3(f), (h)), and are 927 $\pm 5 \mathrm{Ma}(2 \sigma, n=24)$ and $901 \pm 5 \mathrm{Ma}(2 \sigma, n=24)$ using line raster scan mode (Figure 1(f), (h)). They are $\sim 12 \%$ (123-130 Ma) younger than their references values of $1047 \mathrm{Ma}$ and $1014 \mathrm{Ma}$. It is indicate a significant matrix effect between different minerals, i.e. zircon and titanite, by LA-ICPMS technique using single spot and/or line raster scan modes. Some researchers suggested that line raster scan analysis significantly reduce matrix effect $[4,19,20]$, however, our results show that significant matrix effect exist during line raster scan analyses.

In summary, matrix effect significantly exists between different minerals using LA-ICPMS dating. Thus, same kind of minerals should be used as the external standard for LA-ICPMS using single spot and line raster scan modes. It is obvious that the matrix effect is slighting for same minerals with different compositions during LA-ICPMS U-Pb age determination. For example, using BLR-1 titantie as the external standard [32,34], the obtained U-Pb ages of OLT-1 titanite are consistent with its reference value for both single spot and line raster scan analyses, although BLR-1 and OLT-1 titanites have distinct chemical components.

\subsection{Thermal chronology of the Fangshan pluton}

The Fangshan pluton is well known in China because that the Chinese ${ }^{40} \mathrm{~K}-{ }^{40} \mathrm{Ar}$ and ${ }^{40} \mathrm{Ar}-{ }^{39} \mathrm{Ar}$ geostandards (ZBH and ZBJ) were collected from this pluton [43-45]. Thus, its chronological study is important for promoting these geostandards. Previous studies show the ${ }^{40} \mathrm{~K}-{ }^{40} \mathrm{Ar}$ and ${ }^{40} \mathrm{Ar}-{ }^{39} \mathrm{Ar}$ ages are $132.8 \pm 1.3 \mathrm{Ma}$ and $132.7 \pm 0.1 \mathrm{Ma}$ for biotite (ZBH) and are $133.3 \pm 1.5 \mathrm{Ma}$ and $132.8 \pm 0.1 \mathrm{Ma}$ for hornblende (ZBJ) from central granodiorite [43-45]. Our previously published U-Pb ages of zircons in different rocks from the Fangshan pluton using both SIMS and LA-ICPMS gave a narrow age range of 130-133 Ma [23]. Closure temperatures for zircon U-Pb system are usually high than $800^{\circ} \mathrm{C}$ [2], while those of ${ }^{40} \mathrm{~K}-{ }^{40} \mathrm{Ar}$ and ${ }^{40} \mathrm{Ar}^{39} \mathrm{Ar}$ systems for biotite and horblende ranges from 300 to $500^{\circ} \mathrm{C}$ [46]. The closure temperature of $\mathrm{U}-\mathrm{Pb}$ system for titanites from the Fangshan pluton are $750-790^{\circ} \mathrm{C}$, between those of U-Pb system of zircon and ${ }^{40} \mathrm{Ar}-{ }^{39} \mathrm{Ar}$ of biotite and hornblende (Figure 6(a)), which constitutes cooling path of the pluton.

$\mathrm{U}-\mathrm{Pb}$ ages of titanites from quartz monzodiorite (08FS02), medium-grained granodiorites (08FS08 and 08FS10), porphyritic granodiorite (08FS13) and mafic enclaves (08FS07 and 08FS09) of the Fangshan pluton show a narrow age range of 131-133 Ma. It is identical to zircon U-Pb ages (130-133 Ma) [23] and biotite ${ }^{40} \mathrm{Ar}-{ }^{39} \mathrm{Ar}$ age (132.7 $\left.\pm 0.1 \mathrm{Ma}\right)$ [43-45] of this pluton, showing a rapid cooling history of the Fangshan pluton from $\sim 850^{\circ} \mathrm{C}$ (zircon U-Pb system) to $\sim 750^{\circ} \mathrm{C}$ (titanite U-Pb system) to $\sim 350^{\circ} \mathrm{C}$ (biotite ${ }^{40} \mathrm{Ar}-{ }^{39} \mathrm{Ar}$ system) at 130-133 Ma, within $3 \mathrm{Ma}$ (Figure 6(b)).

\section{Conclusions}

Titanite and zircon standards were analyzed using single spot and line raster scan modes, in order to investigate matrix effect during LA-ICPMS U-Pb dating. The main conclusions are as below:

Using BLR-1 titanite as the external standard, both single spot analysis and line raster scan analysis of OLT-1 titanite give identical $\mathrm{U}-\mathrm{Pb}$ ages of $1015 \pm 5 \mathrm{Ma}(2 \sigma, n=24)$ and $1017 \pm 6 \mathrm{Ma}(2 \sigma, n=24)$, well consistent with its reference value of $1014 \mathrm{Ma}$, indicating that titanite can be accurately dated by LA-ICPMS with similar mineral as the external standard.

Using 91500 zircon as the external standard, the obtained $\mathrm{U}-\mathrm{Pb}$ ages of BLR-1 and OLT- 1 titanites are about $12 \%$ younger than their references ages, indicating the significant matrix effect exists between different minerals by LA-ICPMS method using either single spot mode or line raster scan 

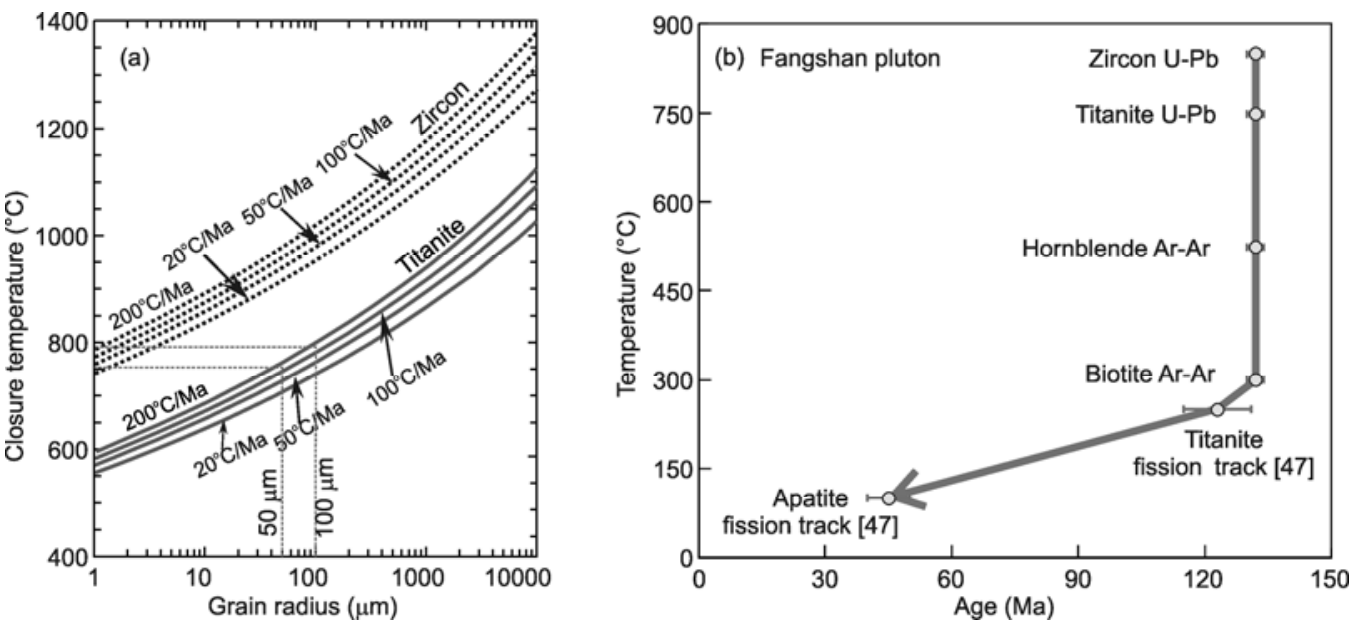

Figure 6 (a) Closure temperature of titanite from the Fangshan pluton. The diffusion coefficients of zircon and titanite are from Zhao and Zheng [48]; (b) cooling history of the Early Cretaceous Fangshan pluton.

mode. Thus, same kind of mineral must be used as the external standard during LA-ICPMS U-Pb dating.

The titanite LA-ICPMS U-Pb dating for six diorite, granodiorite and granite samples give a narrow range of $131-$ $133 \mathrm{Ma}$, identical to their zircon U-Pb and biotite ${ }^{40} \mathrm{Ar}-{ }^{39} \mathrm{Ar}$ ages, implying a rapid cooling history of the Fangshan pluton.

We are grateful to Dr. Aleinikoff J.N. and Kennedy A. for providing BLR-1 and OLT-1 titanites. Two anonymous reviewers are thanked for their thoughtful reviews and constructive comments. This work was supported by the National Natural Science Foundation of China (40925007) and State Key Laboratory of Lithospheric Evolution (Zhuan0809).

1 Sun J F, Yang J H. A review of in-situ U-Pb dating methods for the accessory U-bearing minerals (in Chinese). J Jilin Univ (Earth Science Edition), 2009, 39: 630-649

2 Cherniak D J, Watson E B. Pb diffusion in zircon. Chem Geol, 2001, 172: 5-24

3 Smith H A, Giletti B J. Lead diffusion in monazite. Geochim Cosmochim Acta, 1997, 61: 1047-1055

4 Storey C D, Jeffries T E, Smith M. Common lead-corrected laser ablation ICP-MS U-Pb systematics and geochronology of titanite. Chem Geol, 2006, 227: 37-52

5 Xiang $\mathrm{H}$, Zhang L, Zhong $\mathrm{Z}$ Q, et al. Titanite: U-Pb dating and application on defining $P-T-t$ path of metamorphic rocks (in Chinese). Adv Earth Sci, 2007, 22: 1258-1267

6 Force E R. Geology of titanium-mineral deposits. GSA Spec Pap, 1991, 259: 11-18

7 Frost B R, Chamberlain K R, Schumacher J C. Sphene (titanite): Phase relations and role as a geochronometer. Chem Geol, 2000, 172: 131-148

8 Harlov D, Tropper P, Seifert W, et al. Formation of Al-rich titanite $\left(\mathrm{CaTiSiO}_{4} \mathrm{O}-\mathrm{CaAlSiO}_{4} \mathrm{OH}\right)$ reaction rims on ilmenite in metamorphic rocks as a function of $f \mathrm{H}_{2} \mathrm{O}$ and $f \mathrm{O}_{2}$. Lithos, 2006, 88: 72-84

9 Scott D J, St-Onge M R. Constrains on Pb closure temperature in titanite based on rocks from the Ungava orogen, Canada: Implication for U-Pb geochronology and P-T-t path determination. Geology, 1995, 23: 1123-1126

10 Pidgeon R T, Bosch D, Bruguier O. Inherited zircon and titanite U-Pb systems in an archaean syenite from southwestern Australia: Implications for U-Pb stability of titanite. Earth Planet Sci Lett, 1996, 141: 187-198

11 Corfu F. Multistage zircon and titanite growth and inheritance in Archean gneiss complex, Winnipeg River Subprovince, Ontario. Earth Planet Sci Lett, 1996, 141: 175-186
12 Aleinikoff J N, Wintsch R P, Fanning C M, et al. U-Pb geochronology of zircon and polygenetic titanite from the Glastonbury Complex, Connecticut, USA: An integrated SEM, EPMA, TIMS and SHRIMP study. Chem Geol, 2002, 188: 125-147

13 Tilton G R, Grunenfelder M H. Sphene: Uranium-lead ages. Science, 1968, 159: 1458-1461

14 Black L P, Kamo S L, Allen C M, et al. Improved ${ }^{206} \mathrm{~Pb} /{ }^{238} \mathrm{U}$ microprobe geochronology by the monitoring of a trace-element-related matrix effect: SHRIMP, ID-TIMS, ELA-ICP-MS and oxygen isotope documentation for a series of zircon standards. Chem Geol, 2004, 205: $115-140$

15 Fletcher I R, McNaughton N J, Davis W J, et al. Matrix effects and calibration limitations in ion probe $\mathrm{U}-\mathrm{Pb}$ and $\mathrm{Th}-\mathrm{Pb}$ dating. Chem Geol, 2010, 270: 31-44

16 Willigers B J A, Baker J A, Krogstad E J, et al. Precise and accurate in situ $\mathrm{Pb}-\mathrm{Pb}$ dating of apatite, monazite and sphene by laser ablation multiple-collector ICP-MS. Geochim Cosmochim Acta, 2002, 66: 1051-1066

17 Simonetti A, Heaman L M, Chacko T, et al. In situ petrographic thin section U-Pb dating of zircon, monazite, and titanite using laser ablation-MC-ICPMS. Int J Mass Spectrom, 2006, 253: 87-97

18 Schaltegger U, Brack P, Ovtcharova M, et al. Zircon and titanite recording 1.5 million years of magma accretion, crystallization and initial cooling in a composite pluton (Southern Adamello batholith, northern Italy). Earth Planet Sci Lett, 2009, 286: 208-218

19 Storey C D, Smith M P, Jeffries T E. In situ LA-ICPMS U-Pb dating of metavolcanics of Norrbotten Sweden: Records of extended geological histories in complex titanite grains. Chem Geol, 2007, 240: 163-181

20 Li J W, Deng X D, Zhou M F, et al. Laser ablation ICP-MS titanite $\mathrm{U}-\mathrm{Th}-\mathrm{Pb}$ dating of hydrothermal ore deposits: A case study of the Tonglushan $\mathrm{Cu}-\mathrm{Fe}-\mathrm{Au}$ skarn deposit, SE Hubei Province, China. Chem Geol, 2010, 270: 56-67

21 Gao X Y, Zheng Y F, Chen Y X, et al. Geochemical and U-Pb age constraints on the occurrence of polygenetic titanites in UHP metagranite in the Dabie orogen. Lithos, 2012, 136-139: 93-108

22 Xie L W, Zhang Y B, Zhang H H, et al. In situ simultaneous determination of trace elements, $\mathrm{U}-\mathrm{Pb}$ and $\mathrm{Lu}-\mathrm{Hf}$ isotopes in zircon and baddeleyite. Chin Sci Bull, 2008, 53: 1565-1573

23 Sun J F, Yang J H, Wu F Y, et al. Magma mixing controlling the origin of the Early Cretaceous Fangshan granitic pluton, North China Craton: In situ U-Pb age and $\mathrm{Sr}-$, Nd-, Hf- and O-isotope evidence. Lithos, 2010, 120: 421-438

24 Wu F Y, Yang Y H, Xie L W, et al. Hf isotopic compositions of the standard zircons in U-Pb geochronology. Chem Geol, 2006, 234: $105-126$

25 Yang Y H, Sun J F, Xie L W, et al. In situ Nd isotopic measurement of natural geological materials by LA-MC-ICP-MS. Chin Sci Bull, 
2008, 53: 1062-1070

26 Griffin W L, Powell W J, Pearson N J, et al. GLITTER: Data reduction software for laser ablation ICP-MS. In: Sylvester P, ed. Laser Ablation-ICP-MS in the Earth Sciences: Current Practices and Outstanding Issues: Mineralogical Association of Canada Short Course, 2008, 40: 308-311

27 Andersen T. Correction of common lead in $\mathrm{U}-\mathrm{Pb}$ analyses that do not report ${ }^{204} \mathrm{~Pb}$. Chem Geol, 2002, 192: 59-79

28 Tera F, Wasserburg G J. U-Th-Pb systematics in three Apollo 14 basalts and the problem of initial $\mathrm{Pb}$ in lunar rocks. Earth Planet Sci Lett, 1972, 14: 281-304

29 Stacey J S, Kramers J D. Approximation of terrestrial lead isotope evolution by a two-stage model. Earth Planet Sci Lett, 1975, 26: 207-221

30 Ludwig K R. ISOPLOT 3.0: A geochronological toolkit for Microsoft Excel. Berkeley Geochronology Center, 2003, Spec. Pub 4

31 Aleinikoff J N, Wintsch R P, Tollo R P, et al. Ages and origins of rocks of Killingworth dome, South-Central Connecticut: Implications for the tectonic evolution of southern New England. Am J Sci, 2007, 307: 63-118

32 Mazdab F K. Characterization of flux-grown trace-element-doped titanite using the High-Mass-Resolution Ion Microprobe (SHRIMPRG). Can Mineral, 2009, 47: 813-831

33 Kennedy A, Kamo S, Nasdala L, et al. Grenville skarn titanites: new reference materials for SIMS U-Th-Pb analysis. In: Micro-AnalysisProcesses-Time (MAPT) Conference. Edinburgh, UK, 2009. 89-90

34 Kennedy A, Kamo S, Nasdala L, et al. Grenville skarn titanite: Potential reference material for SIMS U-Th-Pb analysis. Can Mineral, 2010, 48: 1423-1443

35 Kinny P D, McNaughton N J, Fanning C M, et al. 518 Ma sphene (titanite) from the Khan pegmatite, Namibia, southwest Africa: A potential ion-microprobe standard. In: ICOG8. Berkeley, US Geololgical Survey Circular, 1994, 1107: 171

36 Elhlou S, Belousova E, Griffin W L, et al. Trace element and isotopic composition of GJ-red zircon standard by laser ablation. Geochim Cosmochim Acta, 2006, 70(Suppl): A158

37 Liu X M, Gao S, Diwu C R, et al. Simultaneous in-situ determination of U-Pb age and trace elements in zircon by LA-ICPMS in $20 \mu \mathrm{m}$ spot size. Chin Sci Bull, 2007, 52: 1257-1264

38 Ma C Q. The magma-dynamic mechanism of emplacement and compositional zonation of the Zhoukoudian stock, Beijing (in Chinese). Acta Geol Sin, 1988, 4: 329-342

39 He B, Xu Y G, Paterson S. Magmatic diapirism of the Fangshan pluton, southwest of Beijing, China. J Struct Chem, 2009, 31: 615-626

40 Kohn M J, Corrie S L. Preserved Zr-temperatures and U-Pb ages in high-grade metamorphic titanite: Evidence for a static hot channel in the Himalayan orogen. Earth Planet Sci Lett, 2011, 311: 136-143

41 Horn I, Rudnick R L, McDonough W F. Precise elemental and isotope ratio determination by simultaneous solution nebulization and laser ablation-ICP-MS: Application to U-Pb geochronology. Chem Geol, 2000, 167: 405-425

42 Tiepolo M, Bottazzi P, Palenzona M, et al. A laser probe coupled with ICP-double-focusing sector-field mass spectrometer for in situ analysis of geological samples and U-Pb dating of zircon. Can Mineral, 2003, 41: 259-272

43 Wang S S. Age determinations of ${ }^{40} \mathrm{Ar}-{ }^{40} \mathrm{~K},{ }^{40} \mathrm{Ar}-{ }^{39} \mathrm{Ar}$ and radiogenic ${ }^{40} \mathrm{Ar}$ released characteristics on K-Ar geostandards of China (in Chinese). Sci Geol Sin, 1983, 4: 315-323

44 Sang H Q, Wang F, He H Y, et al. Intercalibration of ZBH-25 biotite reference material utilized for $\mathrm{K}-\mathrm{Ar}$ and ${ }^{40} \mathrm{Ar}-{ }^{39} \mathrm{Ar}$ age determination (in Chinese). Acta Petrol Sin, 2006, 22: 3059-3078

45 Sang H Q, Wang F, He H Y, et al. Certified results of the ZBJ hornblende reference materials for $\mathrm{K}-\mathrm{Ar}$ and ${ }^{40} \mathrm{Ar}-{ }^{39} \mathrm{Ar}$ dating (in Chinese). Chin J Geol, 2007, 42: 532-557

46 Harrison T M, McDougall I. The thermal significance of potassium feldspar $\mathrm{K}$-Ar ages inferred from ${ }^{40} \mathrm{Ar} /{ }^{39} \mathrm{Ar}$ spectrum results. Geochim Cosmochim Acta, 1982, 46: 1811-1820

47 Zhai P J, Zhang F, Zhao Y L. Thermal history of the Fangshan granodiorite intrusion, Beijing: Evidence from fission tracks of apatites and sphenes (in Chinese). Geochimica, 2003, 32: 188-192

48 Zhao Z F, Zheng Y F. Diffusion compensation for argon, hydrogen, lead, and strontium in minerals: Empirical relationships to crystal chemistry. Am Mineral, 2007, 92: 289-308

Open Access This article is distributed under the terms of the Creative Commons Attribution License which permits any use, distribution, and reproduction in any medium, provided the original author(s) and source are credited.

\section{Supporting Information}

Table S1 LA-ICPMS U-Pb data for BLR-1, OLT-1 and Ontario titanites (BLR-1 titanite as the external standard)

Table S2 LA-ICPMS U-Pb data for GJ-1 zircon (91500 zircon as the external standard)

Table S3 LA-ICPMS U-Pb data for BLR-1 and OLT-1 titanites (91500 zircon as the external standard)

Table S4 LA-ICPMS U-Pb data for titanites from the Early Cretaceous Fangshan pluton, North China Craton

The supporting information is available online at csb.scichina.com and www.springerlink.com. The supporting materials are published as submitted, without typesetting or editing. The responsibility for scientific accuracy and content remains entirely with the authors. 